\title{
Deer Use of a Right-of-Way in Central Pennsylvania, U.S.
}

\author{
Richard H.Yahner
}

\begin{abstract}
The purpose of the State Game Lands (SGL) 33 Research and Demonstration Area, since its inception in 1953, has been to compare the effectiveness of commonly used mechanical and herbicidal maintenance treatments on vegetation and wildlife on a right-of-way (ROW). White-tailed deer (Odocoileus virginiana) use of the SGL 33 Research and Demonstration Area, Center County, Pennsylvania, U.S. was reported over 20 years ago. As part of a 2-year study before and just after maintenance of the SGL 33 ROW, I examined deer use of the ROW in 2006 to 2007. Deer can have a positive impact on a ROW by browsing on undesirable trees (those capable of growing tall) in wire and border zones of a ROW and providing aesthetic value to a ROW; however, deer can have a negative impact on adjacent forest health by feeding on herbaceous and woody vegetation. In this study, I determined relative use by deer of the ROW, which is maintained by the wire-border zone method and using integrated vegetative management. Deer use of the ROW in 2006 to 2007 was minimal, which I attribute primarily to the lack of grass cover type as a food resource.
\end{abstract}

Key Words. herbicidal; maintenance; mechanical; right-of-way; vegetation.

There have been two objectives at the State Game Lands (SGL) 33 Research and Demonstration Project in central Pennsylvania, U.S. since 1953: 1) to compare commonly used mechanical and herbicidal maintenance treatments on controlling target trees (trees capable of growing tall in wire zones and possibly causing a blackout, hereafter termed undesirable) and development of tree-resistant plant cover types; and 2) to determine the effectiveness of mechanical and herbicidal maintenance on vegetation and wildlife species of high public interest (Yahner and Hutnik 2004). In 1982, the wire-border zone method of vegetation management was implemented on the right-of-way (ROW) of the SGL 33 Research and Demonstration Project (Bramble et al. 1985; Yahner and Hutnik 2004). This method usually results in a tree-resistant forb-shrub-grass cover type in wire zones but a tall shrub cover type in border zones, thereby producing wildlife habitat diversity on the ROW.

White-tailed deer (Odocoileus virginianus) may be an important wildlife species on an electric transmission ROW by browsing on undesirable tree species (Bramble et al. 1985). Deer also can impact regeneration and growth of herbaceous vegetation in the adjacent forest (Yahner 2000; Pennsylvania Game Commission 2003). Because deer have tremendous recreational value, prefer early successional habitat (e.g., that created by vegetation management of a ROW), and can have profound effects on forest health, studies of deer on a ROW are important.

\section{STUDY AREA AND METHODS}

In 2000, vegetation on the SGL 33 Research and Demonstration Area was treated (details of the treatments are given in Yahner and Hutnik 2004, 2005). The area comprised two units each of handcut (HC), mowing (M), mowing plus herbicide $(\mathrm{MH})$, stem-foliage spray (SF), foliage spray (F), and lowvolume basal spray (BLV). In June 2007, the entire ROW again was treated (details are given in Yahner 2007), but treatment was after the major portion of the growing season. Hence, I believe plant succession had minimal effect on deer populations in the later part of 2007.

Units selected for this study were accessible by vehicle and contained dominant life forms (tree, shrub, forb, and grass), including two units of $\mathrm{M}, \mathrm{MH}, \mathrm{SF}$, and BLV and one unit of $\mathrm{HC}$ and $\mathrm{F}$. The area surveyed for deer use comprised approximately $67 \%$ of the total ROW.

Forest cover was located adjacent to the entire length of the ROW, and dominant trees were red maple (Acer rubrum), chestnut oak (Quercus montanus), northern red oak (Q. rubra), white oak ( $Q$. alba), and black oak ( $Q$. velutina) (Bramble et al. 1992). Tree sprouts were produced in the HC unit with common tree species being black cherry (Prunus serotina) and chestnut, northern red, white, black, and scrub ( $Q$. ilicifolia) oaks.

Tall shrub cover type predominated in border zones of several treatment units, e.g., mowing plus herbicide, with a dominant tall shrub of witchhazel (Hamamelis virginiana) (Bramble et al. 1992). Short shrub cover type commonly occurred in wire zones of some units, e.g., basal low-volume spray, and the principal plant species were blueberry (Vaccinium vacillans and V. angustifolium), huckleberry (Gaylussacia baccata), and sweetfern (Comptonia peregrina). Cane thicket cover type was present in pure stands of some wire zones, e.g., basal low-volume spray, and the major species was common blackberry (Rubus allegheniensis). Forb-shrub cover type was common in wire zones of mowed plus herbicide units; major species included goldenrod (Solidago rugosa and Euthamia graminifolia), hayscented fern (Dennstaedtia punctilobula), and sweet-fern.

Deer were surveyed 6 days per month from March 2006 through October 2007 ( 3 days at dusk and 3 days at sunrise) using spotlighting or visual observations with field glasses in the ten units accessible from a vehicle (after Storm et al. 1992). Spotlighting was discontinued after March 2006 mainly because it was difficult to determine sex and age of deer. Number (and percent) of undesirable trees/ac 30 to $91 \mathrm{~cm}$ tall $(1$ to $3 \mathrm{ft}$ ) in wire zones and border zones of two replicates of five different units that showed evidence of browsing by deer were noted in June 2006, just after leaf-out. Data were combined from seven 
tree species, e.g., black cherry (Prunus serotina), red maple (Acer rubrum), white oak (Quercus alba), chestnut oak ( $Q$. montanus), northern red oak ( $Q$. rubra), black oak ( $Q$. velutina), and sassafras (Sassafras albidum). Total number (all species combined) of browsed trees was compared between wire and border zones using a $\chi^{2}$ goodness-of-fit test (Sokal and Rohlf 1995). In addition, pellet groups, tracks, and other signs found opportunistically (e.g., buck rubs) along established transects used for vegetative sampling were noted (details of transects are given in Yahner and Hutnik 2004, 2005) in the entire ROW (15 units). Pellet groups were monitored in March 2006, and tracks were counted 2 days after each snowfall.

\section{RESULTS AND DISCUSSION}

Only nine and 11 deer were observed on the ROW in 2006 and 2007 , respectively. This low number of deer using the ROW is not unexpected because deer are highly mobile (Storm et al. 1995), early successional habitat was lacking on the SGL 33 ROW (Smith and Coggin 1984), the ROW traverses mature forest (greater than 80 years since last cutting), and the general region (including the ROW) is hunted regularly for deer. Based on 8 months per year and 6 days per month, this is 2.1 deer per 10 days of observation on the ROW during both years combined from March to October. By comparison, over twice as many (4.8 deer per 100 days; $n=$ 42 total deer) were seen in fields within $5 \mathrm{~km}$ of the ROW or in food plots established by the Pennsylvania Game Commission within an approximate 500 and $150 \mathrm{~m}$ of the ROW. These food plots were planted in pasture mixes of grasses and mowed periodically to encourage sprouting of nutritive food for deer (Forbes et al. 1971). When compared with the ROW at SGL 33, 22 deer were seen on the Green Lane ROW in Montgomery County, southeastern Pennsylvania in 2007, which equates to nearly sevenfold the number of deer (13.8 deer per 10 days) per observation day (Yahner 2007). Moreover, no deer were seen along roads or in fields in 2007 within $5 \mathrm{~km}$ of the Green Lane ROW. This suggests that both deer populations and suitable habitat on the ROW are less on the SGL 33 ROW compared with the Green Lane ROW. The Green Lane ROW traverses residential areas, which are not heavily hunted by deer hunters, and the Green Lane ROW was maintained in 2004 (Yahner 2006), thereby providing less hunting pressure, combined with more suitable habitat, e.g., grass cover type, on and in the general region of the ROW (Smith and Coggin 1984).

Browsing by deer on undesirable tree species was greater $(70 \%$ of total trees browsed) in wire zones compared with border zones $(50 \%)\left(\chi^{2}=6.7, \mathrm{df}=1, P=0.01\right.$; Table 1$)$. Regardless of treatment, average percentage of undesirable trees was at least $50 \%$ in wire zones of all treatments, but browsing did not exceed $50 \%$ in only two of the five treatments in border zones. Perhaps deer readily found browse in the more "open" wire zones than in the "closed" border zones. Trees and shrubs in border zones likely impeded movements and raised the energetic costs of foraging by deer in border than in wire zones. In comparison, only $30 \%$ of undesirable trees of height in the contiguous forest, which were similar in height to those on the adjacent ROW, were browsed by deer.

Tracks of ten deer were detected; all tracks were found in border zones. However, I viewed this as an unreliable indication of deer use of the ROW for two reasons. First, tracks are ephemeral and may not be a good method to detect deer use of the ROW.

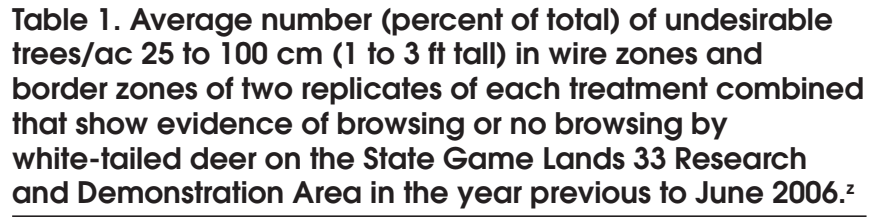
and Demonstration Area in the year previous to June 2006. ${ }^{2}$

\begin{tabular}{llllll}
\hline \multirow{2}{*}{$\begin{array}{l}\text { Treatment unit } \\
\text { (replicate) }\end{array}$} & \multicolumn{2}{c}{ Wire zone } & & \multicolumn{2}{c}{ Border zone } \\
\cline { 2 - 3 } \cline { 6 - 7 } & Browsed & Unbrowsed & & Browsed & Unbrowsed \\
\hline Mowing & $31(72)$ & $12(28)$ & & $18(62)$ & $11(28)$ \\
Mowing plus herbicide & $15(63)$ & $9(37)$ & & $13(52)$ & $12(48)$ \\
Stem-foliage spray & $18(78)$ & $5(22)$ & & $19(79)$ & $5(21)$ \\
Foliage spray & $24(80)$ & $6(20)$ & & $9(33)$ & $18(67)$ \\
Basal low volume & $10(50)$ & $10(50)$ & & $7(30)$ & $21(70)$ \\
All units & $98(70)^{y}$ & $42(30)$ & & $66(50)$ & $67(50)$ \\
\hline
\end{tabular}

${ }^{\mathrm{z}}$ Data are combined from undesirable tree species, e.g., black cherry (Prunus serotina), red maple (Acer rubrum), white oak (Quercus alba), chestnut oak (Q. montanus), northern red oak $(Q$. rubra), black oak $(Q$. velutina), and sassafras (Sassafras albidum).

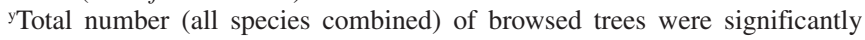
greater in wire zones than in border zones. $\chi^{2}$ goodness-of-fit test; $\chi^{2}=6.7$, df $=1, P=0.01$

Second, more tracks in border zones rather than in wire zones might be expected because of the cover afforded by border zones (deer more cryptic, protection against wind) and because of the high winds that caused snow drifting over potential tracks in wire zones. Only two pellet groups were found within established transects with one each per zone. Two buck rubs were noted along the entire ROW (one per zone).

In the next couple of years with the progression of plant succession after maintenance in late June 2007, I would expect more deer to use the ROW beginning in Spring 2008. I would predict greater deer use of the ROW, especially in units containing appreciable grass cover, likes with mowing and mowing plus herbicide units. Deer are known not only as browsers, but also as grazers (Beier 1987; Cypher et al. 1988). Adult females, in particular, more so than adult males, use grass as a food resource on a year-round basis (Beier 1987; McCullough et al. 1989). Thus, future years of research should indicate greater use, and perhaps greater abundance, of deer on the State Game Lands 33 ROW.

Acknowledgments. Cooperators were Asplundh Tree Expert Co., Dow AgroSciences, FirstEnergy (Penelec), and the Pennsylvania Game Commission. I thank R.T. Yahner and T.R. Yahner for field assistance.

\section{LITERATURE CITED}

Beier, P. 1987. Sex differences in quality of white-tailed deer diets. Journal of Mammalogy 68:323-329.

Bramble, W.C., W.R. Byrnes, and R.J. Hutnik. 1985. Effects of a special technique for right-of-way maintenance on deer habitat. Journal of Arboriculture 11:278-284.

Bramble, W.C., R.H. Yahner, W.R. Byrnes, and S.A. Liscinsky. 1992. Small mammals in plant cover types on an electric transmission rightof-way. Journal of Arboriculture 18:316-321.

Cypher, B.L., R.H. Yahner, and E.A. Cypher. 1988. Seasonal food use by white-tailed deer in southeastern Pennsylvania. Environmental Management 12:237-242.

Forbes, S.E., L.M. Lang, S.A. Liscinsky, and H.A. Roberts. 1971. The white-tailed deer in Pennsylvania. Res. Bull. 170. Pennsylvania Game Commission, Harrisburg, PA. 41 pp.

McCullough, D.R., D.H. Hirth, and S.J. Newhouse. 1989. Resource partitioning between sexes in white-tailed deer. The Journal of Wildlife Management 53:277-283. 
Pennsylvania Game Commission. 2003. Population management plan for white-tailed deer in Pennsylvania. Pennsylvania Game Commission, Bureau of Wildlife Management. 45 pp. www.pgc.state.us/pgc (accessed 12/2007).

Smith, R.L., and J.L. Coggin. 1984. Basis and role of management. In: McCabe, R.E., and L.R. Jahn (Tech. Eds.). White-Tailed Deer: Ecology and Management. Stackpole Books, Harrisburg, PA.

Sokal, R.R., and F.J. Rohlf. 1995. Biometry. 3rd Ed. W.H. Freeman and Company, New York, NY. 887 pp.

Storm, G.L., D.F. Cottam, and R.H. Yahner. 1995. Movements and habitat use by female deer in historic areas at Gettysburg, Pennsylvania. Northeast Wildlife 52:49-58.

Storm, G.L., D.F. Cottam, R.H. Yahner, and J.D. Nichols. 1992. Estimating density of deer at Gettysburg National Park. Wildlife Society Bulletin 20:197-203.

Yahner, R.H. 2000. Eastern Deciduous Forest: Ecology and Wildlife Conservation. 2nd Ed. Univ. Minnesota Press, Minneapolis, MN. 295 pp. 2006. Green Lane Research and Demonstration Project: 20 Years of Continuous Study. Annual Report to Cooperators. 36 pp.

- 2007. State Game Lands 33 Research and Demonstration Project-55 Years of Continuous Study. Annual Report to Cooperators. 35 pp.

Yahner, R.H., and R.J. Hutnik. 2004. Integrated vegetation management on an electric transmission right-of-way in Pennsylvania, U.S. Journal of Arboriculture 30:295-300.

- 2005. Plant species richness on an electric transmission right-ofway using integrated vegetation management. Journal of Arboriculture 31:124-130.

Richard H. Yahner

School of Forest Resources

Penn State University

University Park, PA 16802, U.S.

rhy@psu.edu

Résumé. Le but de l'aire de démonstration et de recherche SGL 33 (State Game Land 33), depuis sa mise en place en 1953, a été de comparer l'efficacité de méthodes mécaniques et chimiques communes pour le contrôle et l'entretien de la végétation ainsi que de la faune au sein d'une emprise de ligne électrique. La fréquentation par le cerf de Virginie (Odocoileus virginiana) de l'aire de démonstration et de recherche SGL 33 dans le comté de Center en Pennsylvanie a été documentée durant 20 ans. Dans le cadre d'une étude de 2 ans avant et après une intervention d'entretien sur cette emprise, nous avons étudié l'utilisation de ce corridor par le cerf en 2006 et 2007. Le cerf peut avoir un impact positif sur l'emprise en broutant les arbres indésirables (ceux capables de pousser en hauteur), et ce autant à l'intérieur du corridor qu'en bordure, ainsi qu'en procurant une valeur esthétique à l'emprise; cependant, le cerf peut avoir un impact négatif sur la santé de la forêt adjacente en s'alimentant sur la végétation herbacée et ligneuse. Dans cette étude, on a déterminé l'usage relatif de l'emprise par le cerf, emprise qui était entretenue selon la manière classique et par l'emploi de méthodes de gestion intégrée de la végétation. L'utilisation de l'emprise par le cerf en 2006 et 2007 était minimal, ce qui était attribué principalement au manque de couvert herbacé comme source de nourriture.

Zusammenfassung. Die Aufgabe der SGL 33 Forschungsund Demonstrationsfläche seit ihrer Anlage im Jahre 1953 ist es, die Effektivität von weithin genutzten mechanischen und chemischen Kontrollen von Pflanzen und Tieren im Bereich von Überlandleitungen zu vergleichen. Das Vorkommen von Weißschwanz-Hirschen im Bereich der SGL33-Flächen wird seit 20 Jahren berichtet. Als Teil einer 2jährigen Studie vor und gerade nach der Durchführung von Erhaltungs- bzw. Pflegemaßnahmen in der SGL 33-Fläche, habe ich das Vorkommen der Hirsche von 2006-2007 untersucht. Die Hirsche können einen positiven Effekt auf die Flächen haben, indem sie unerwünschte Bäume im Bereich der Leitungen und in den Randzonen verbeissen. Sie liefern damit auch einen ästhetischen Nutzen für die Fläche. Trotzdem haben sie auch einen negativen Einfluss auf die benachbarten Forstflächen, weil sie dort ebenfalls Pflanzen verbeissen. Ich untersuchte in dieser Studie den relativen Nutzen von Hirschen im Bereich der Überlandleitungen, welche durch den Einsatz von Integrierten Pflanzenschutzmaßnahmen gepflegt werden. Das Vorkommen von Hirschen im untersuchten Bereich in den Jahren 2006-2007 war minimal, was ich hauptsächlich auf den Mangel an Gras als Futtergrundlage zurückführe.

Resumen. El propósito del Área de Demostración e Investigación 33 (SGL), desde su inicio en 1953, ha sido comparar la efectividad de los comúnmente usados tratamientos mecánicos y herbicidas sobre la vegetación y vida silvestre en un derecho de vía (ROW). El uso del venado cola blanca (Odocoileus virginiana) en el Área de Investigación SGL 33 se ha reportado desde hace 20 años. Como una parte de un estudio de 2 años antes y justo después del mantenimiento de SGL 33 ROW, se examinó el uso del venado en el ROW en 2006 a 2007. El venado puede tener un impacto positivo en un ROW ramoneando árboles indeseables (aquellos capaces de crecer en altura) en zonas con alambre y de frontera de un ROW y dar valor estético al mismo; sin embargo, el venado puede tener un impacto negativo en bosques saludables adyacentes mediante su alimentación con herbáceas y vegetación leñosa. En este estudio, se determinó el uso relativo del venado del ROW, el cual es mantenido por el método de zona con alambre y el uso de manejo integrado de vegetación. El uso del venado en el ROW en 2006 a 2007 fue mínimo, lo cual se atribuye primariamente a la falta de tipo de cobertura de pastos como una fuente de alimento. 